\title{
Church of Jesus Christ of Latter-day Saints
}

David C. Dollahite

Brigham Young University - Provo, david_dollahite@byu.edu

Follow this and additional works at: https://scholarsarchive.byu.edu/facpub

Part of the Other Social and Behavioral Sciences Commons

\section{Original Publication Citation}

Dollahite, David C. (2014). "Church of Jesus Christ of Latter-day Saints." Pp. 236-238 in Marilyn Coleman \& Lawrence Ganong (Eds.) Social History of the American Family, vol 1. Thousand Oaks, CA: Sage.

\section{BYU ScholarsArchive Citation}

Dollahite, David C., "Church of Jesus Christ of Latter-day Saints" (2014). Faculty Publications. 4992. https://scholarsarchive.byu.edu/facpub/4992

This Other is brought to you for free and open access by BYU ScholarsArchive. It has been accepted for inclusion in Faculty Publications by an authorized administrator of BYU ScholarsArchive. For more information, please contact ellen_amatangelo@byu.edu. 
See Also: Catholicism; Christianity; Church of Jesus Christ of Latter-day Saints; Easter.

\section{Further Readings}

Etzioni, A. “Toward a Theory of Public Ritual.” Sociological Theory, v.18 (2000).

Stronach, I. and A. Hodkinson. "Towards a Theory of Santa: Or, the Ghost of Christmas Present." Anthropology Today, v.27/6 (2011).

Thomas, J. B. and C. Peters. “An Exploratory Investigation of Black Friday Consumption Rituals.” International Journal of Retail \& Distribution Management, v.39 (2011).

\section{Church of Jesus Christ of Latter-day Saints}

The Church of Jesus Christ of Latter-day Saints (LDS) was formally organized on April 6, 1830, in Palmyra, New York, by founding president Joseph Smith during the era of U.S. history known as the Second Great Awakening. Smith was considered a prophet, through whom God restored the church of that Latter-day Saints (i.e., the Mormons), believed to be lost to apostasy in ancient times.

As of the early 21st century, there are about 15 million Mormons in the world, including about 6 million in the United States, making Mormonism the fourth largest denomination of Christians in the United States. The LDS Church is based in Salt Lake City, Utah, which was founded by Mormon leader Brigham Young and several others in 1847, three years after Smith was killed by a mob in Carthage, Illinois, as the result of his controversial religious views. As of 2012, about 62.5 percent of Utah's population identified as Mormon. In addition to the Bible, the LDS Church also has several other canonical texts, including the Book of Mormon, the Doctrine and Covenants, and the Pearl of Great Price.

\section{Familial Nature of God}

Latter-day Saints believe that the Godhead consists of God the Eternal Father, His Son Jesus Christ, and the Holy Ghost. Unlike the Christian Trinity, in which there is only one God, manifest in three aspects, Mormons believe the members of the Godhead are separate, distinct persons. God the Father and Jesus each have a glorified body of flesh and bones, while the Holy Ghost is a personage of spirit. Mormons pray to Heavenly Father, in the name of Jesus Christ, by the power of the Holy Ghost.

Mormons believe God the Eternal Father is literally the father of the soul (spirit) of every person who has ever lived. Mormons also believe that not only do all human beings have an Eternal Father, but also an Eternal Mother. So, every person's soul is literally the offspring of heavenly parents. Thus, there is a eternal familial relationship between God and all human beings. This emphasis on the familial nature of the relationship between God and humanity is distinct from most other religions that teach that human beings are creatures, not literal children, of God. This doctrine of God is central to how Mormons think about all aspects of life.

\section{The Plan of Happiness}

The plan of happiness (the plan of salvation, or the great plan of redemption) is a system of doctrines that answer the questions: Where were people before birth? Why are they on earth? Where do they go when they die? The plan teaches that before birth, all individuals lived with God as His spirit sons and daughters, where they accepted God's plan to come to Earth to progress toward becoming more like God. The purpose of Earth life is to gain a physical body, make choices, be tested in a place of opposition and temptation, and learn to form families. When people die, their spirits (souls) go to the spirit world, where they continue to learn and grow and make choices, and at some point, all human beings will receive a resurrected body of flesh and bones. All human beings have the potential to form eternal marriages and families. 


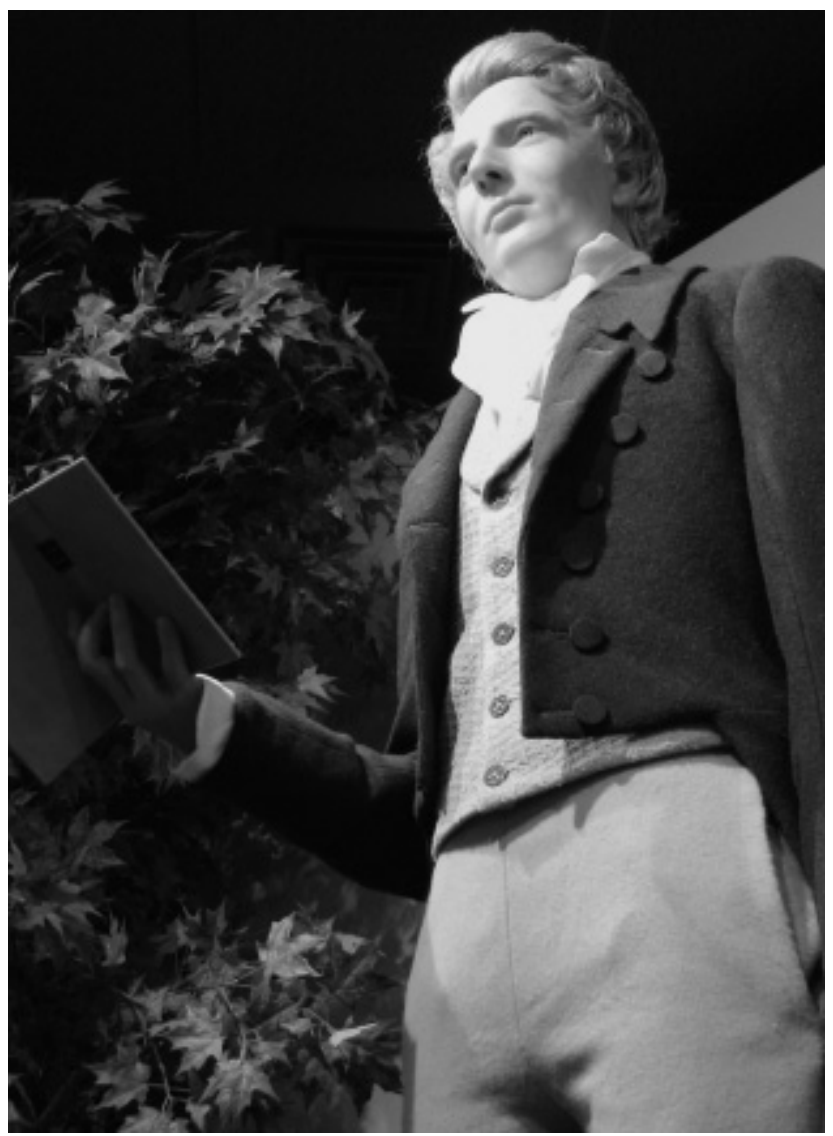

A statue of Joseph Smith stands holding a copy of the Book of Mormon at the North Visitors' Center, Temple Square, at the Church of Jesus Christ of Latter-day Saints.

\section{Plural Marriage}

Joseph Smith taught a set of distinctive doctrines pertaining to marriage and family life, including what Mormons call "plural marriage" (more commonly known as polygyny, or one husband with multiple wives). The practice of plural marriage was considered a divinely sanctioned restoration of biblical marriage as practiced by Abraham, Isaac, Jacob, David, Solomon, and others in the Old Testament. Although polygyny has been practiced in many cultures throughout world history, it was considered wrong and strange in 19th-century United States and Europe. Thus, Mormons suffered persecution from other Americans for this practice, and the government of the United States enacted laws against it, including disenfranchising the church and confiscating its property.

Wilford Woodruff, fourth president of the LDS Church, announced in 1890 that he had received a revelation to discontinue plural marriage. Thus, of the roughly 185 years that the LDS Church has been in existence, plural marriage was sanctioned for only about 50 of them. Although plural marriage may have characterized 19th-century Mormonism, contemporary LDS marriage and family life is decidedly traditional in that the church and its members has become one of the strongest proponents of marriage between one man and one woman.

\section{Eternal Marriage and Family}

Although most people know that Mormons once practiced plural marriage, relatively few know the most central Mormon doctrine on marriage and family - eternal marriage and family. Smith taught the doctrine that God has made it possible for marriage and family life to transcend death and last throughout eternity, and this belief is central to the LDS Church. Mormons believe that God intends for marriage to be eternal. Thus, in LDS temples, couples are "sealed" to one another, and are considered married "for time and all eternity," rather than until death. Mormons believe that this doctrine is consistent with the biblical passage in which the Apostle Paul states in 1 Corinthians 11:11 that "neither is the man without the woman, neither the woman without the man, in the Lord." 
The doctrine of eternal marriage provides inspiration for LDS couples to marry and to strive to strengthen and preserve their marriage in the face of the many challenges to marital happiness and stability found in contemporary Western culture. Latter-day Saints have a high rate of marriage and marry, on average, a few years earlier than the national average. Couples married in LDS temples also have a lower divorce rate than the general population. The doctrine of eternal marriage also provides solace to widows and widowers, who look past the temporary separation that death of a spouse brings, and toward an eternal reunion with their departed loved one.

\section{Eternal Families}

Latter-day Saints believe that children born to couples that have been sealed in an LDS temple are "born in the covenant," and are thus sealed to the parents throughout time and eternity. Converts to the LDS Church may go to temples with their children and be sealed to them. Therefore, LDS doctrine emphasizes the eternal nature of family relationships. LDS couples tend to have more children than the national average, and strive to live a family-centered life. There are a number of couple- and family-oriented religious practices that the devout engage in, including couple prayer, family home evening, family prayer, and scripture study. Daily couple prayer is practiced among LDS married couples. Mormons are encouraged to pray as individuals each day, and married couples also join together in daily prayer. This practice fosters greater unity, harmony, and marital love. Couples with children-even young children - are also encouraged to have daily family prayer.

In the early 19th century, LDS Church leaders encouraged families to hold a weekly family home evening (FHE; also called home evenings, or family night). Toward that end, the church sets aside Monday evenings for FHE by not allowing any other church gatherings to be scheduled then. FHE typically involves the family gathering in the home to do things such as sing hymns, study scriptures, have fun, play games, share religious lessons, have religious discussions, and enjoy refreshments.

\section{Family History and Genealogy}

Mormons believe that every person who has ever lived is a literal daughter or son of the Heavenly Father and Heavenly Mother. Therefore, every person is a spiritual brother or sister to every human being who has ever lived. Every person is a beloved eternal child of God, and their goal is to ensure that everyone has the opportunity to hear and accept the gospel and obtain salvation.

Jesus taught that only those who believe in him and are baptized may enter the kingdom of God and enjoy eternal life. Smith taught that God has made provisions for every person who has ever lived on Earth to have an opportunity to hear the fullness of the restored gospel of Jesus Christ (that is, the gospel taught by the Church of Jesus Christ of Latter-day Saints). The vast majority of humanity that has lived on Earth has not had the opportunity to hear about Jesus Christ, much less the restored gospel. Mormons believe that every single person will be fully taught the doctrines and ordinances of the restored gospel either in this life or after death when their souls are in the spirit world. Jesus taught that "the hour is coming, in the which all that are in the graves shall hear his voice" (John 5:28), which Mormons interpret to mean that the gospel will be taught to those in the spirit world. Additionally, Jesus stated that to be saved, a person must be baptized. Smith taught that those people who accept the gospel of Jesus Christ in the spirit world must have someone be baptized for them in order for them to be saved.

Thus, Mormons search out the names of their deceased ancestors and go to LDS temples in order to be baptized by immersion on their behalf. In addition to baptism, they perform other vicarious ordinances (sacraments), such as sealing of couples and families on behalf of deceased persons. This means that practicing Mormons conduct much genealogical research in an effort to create strong connections across generations and create eternal families.

\section{Temple Attendance}

Practicing Mormons worship each Sunday in LDS chapels, which are sometimes called meeting houses. The service includes the sacrament of the Lord's Supper in remembrance of the suffering and death of Jesus. They also teach each other the doctrines of the gospel, and discuss how to best live gospel principles in a challenging and changing world. Because it is only in LDS temples in which members may perform the sacred ordinances for deceased persons, attending temple on a regular basis is an important part of being a practicing Mormon. In the early 21st century, 170 Mormon temples exist throughout the world. 
Like most other religious bodies, the LDS Church teaches that heterosexual marriage is the foundation of society. Because of its central and strong commitment to marriage, the church and its members have actively opposed efforts to redefine marriage to include same-sex couples. The church maintains that these efforts are not driven by hatred or fear of homosexual persons, but rather as a way to preserve traditional marriage as a union between a man and a woman. The church supports efforts to prevent legal discrimination against gays and lesbians, and it opposes any form of violence or hostility toward them.

David C. Dollahite Brigham Young University

See Also: Christianity; Cults; Evangelicals; Sunday School.

\section{Further Readings}

Dollahite, David C. "Latter-day Saint Marriage and Family Life in Modern America." In American Religion and the Family: How Faith Traditions Cope With Modernization, Don S. Browning and David A. Clairmont, eds. New York: Columbia University Press, 2007.

Dollahite, David C. and Loren D. Marks. "The Mormon American Family." Ethnic Families in America: Patterns and Variations, 5th ed. Upper Saddle River, NJ: Pearson, 2010.

Hawkins, Alan J., David C. Dollahite, and Thomas W. Draper. Successful Marriages and Families: Proclamation Principles and Research Perspectives. Provo, UT: BYU Studies Press, 2012.

Ludlow, Daniel H. The Encyclopedia of Mormonism. New York: Macmillan, 1992. http://eom.byu.edu (Accessed December 2013).

\section{Circumcision}

The circumcision of male infants is one of the most common surgical procedures performed in the world, and is the most common surgery performed in the United States. While adolescent and adult males sometimes undergo circumcision, the procedure is most commonly performed on newborns, typically within a few days, weeks, or months following birth. The procedure involves removal of up to 50 percent of the foreskin (or prepuce) of the penis, thereby fully exposing the glans. In some instances, the frenulum (a ridge of skin that connects the prepuce to the glans) is also cut, and in some cases, an incision may be made on the glans. Male circumcision has a long history, and is one of the oldest recorded surgical procedures in the world. It is carried out for a variety of religious, social, and medical purposes. Yet, the procedure has been and continues to be widely contested, particularly as scientific evidence about the health benefits associated with circumcision are debated. Current objections to the routine circumcision of newborns are raised by those who believe that the practice is a fundamental violation of the individual rights to bodily integrity.

Historically, circumcision has served a religious function, and has also been used to promote a variety of social and medical aims. In Judaism, circumcision symbolized a covenant with God, and is believed to go back as far as Abraham. The procedure is typically carried out on the eighth day following birth, and is generally performed by a trained individual known as a mohel. Within Islam, the ritual of circumcision is known as kitan or khatna, which symbolizes cleanliness, used to be carried out as a rite of puberty when a boy was between 7 and 10 years old, but now it is more commonly performed in a hospital following a boy's birth. In ancient times, circumcision was frequently used in a context of social control and warfare. For example, it was used to physically mark slaves. It was also used as a means to celebrate military conquests, as victors would remove the foreskin of members of the opposing force and collect them in a bag, displaying them as war trophies.

During the 19th, 20th, and 21st centuries, circumcision has been promoted as a "cure-all" of sorts, a way to treat or prevent a variety of illnesses and conditions. For example, in earlier decades, circumcision was touted as a means to prevent masturbation and the "perverse" mentality that was attributed to men and boys who were caught engaging in the practice. During the early and into the mid-20th century, circumcision was also promoted as a means to cure or treat paralysis, hip disease, nervous conditions, and antisocial behavior, and prevent penile cancer, skin conditions such as eczema, tuberculosis, and imbecility. It was also endorsed by 